Syntax Literate: Jurnal Ilmiah Indonesia p-ISSN: 2541-0849

e-ISSN: 2548-1398

Vol. 5, No. 8, Agustus 2020

\title{
PERKAWINAN SASI MENURUT HUKUM ADAT DI DESA WASBAKAT KECAMATAN AIRBUAYA
}

\section{Lutfi Rumkel}

Universitas Iqra Buru (UNIQBU) Maluku, Indonesia

Email: lutfirumke19@gmail.com

\section{Abstract}

The sasi marriage process carried out by some Buru people in Wasbakat Village is thick with customs including the customs in organizing marriages. This study aims to study and analyze the implementation of sasi marriage values according to customary law in Wasbakat Village, Airbuaya District, Buru Regency. This research is normative juridical research. The implementation of values in sasi marriages is examined through the legislation approach, concepts, and case approaches by prioritizing the use of legal material through library studies and then analyzed with supporting theories to be able to describe the various findings of sasi marriages. The method used in this research is a descriptive qualitative method. Data obtained from primary data and secondary data with data sources derived from community leaders and the Wasbakat Village community. The method in this research is an observation with nonparticipatory observation techniques, in-depth interviews (interviews), documentation studies, and literature studies. Data analysis stage, includes data reduction, data presentation, and drawing conclusions. The outputs of this research are (1) scientific publications in ISSN journals even if they allow scientific publications in accredited national journals. (2) socializing the results of research to the relevant Regional Government in Buru Regency and the Village apparatus in Wasbakat Village regarding sasi marriage in terms of customary law.

Keywords: Implementation, values, customary law, sasi marriage, wasbakat

\section{Abstrak}

Proses pernikahan sasi yang dilakukan oleh sebagian masyarakat Buru yang ada di Desa Wasbakat kental dengan adat-istiadat termasuk adat dalam penyelenggaraan pernikahan. Penelitian ini bertujuan mengkaji dan menganalisis implementasi nilainilai perkawinan sasi menurut hukum adat di Desa Wasbakat Kecamatan Airbuaya Kabupaten Buru. Penelitian ini merupakan penelitian yuridis normatif. Implementasi nilai-nilai dalam perkawinan sasi ini diteliti melalui pendekatan perundang-undangan, konsep, dan pendekatan kasus dengan mengutamakan penggunaan bahan hukum melalui studi kepustakaan dan kemudian dianalisis dengan teori-teori pendukung untuk dapat mendeskripsikan berbagai temuan tentang perkawinan sasi. Metode yang digunakan dalam penelitian ini adalah metode deskriptif kuaitatif. Data diperoleh dari data primer dan data sekunder dengan sumber data berasal dari tokoh masyarakat dan 
masyarakat Desa Wasbakat. Metode dalam penelitian ini adalah observasi dengan teknik observasi non partisipatif, wawancara mendalam (interview), studi dokumentasi, dan studi literatur. Tahap analisis data, meliputi pereduksian data, penyajian data, dan penarikan kesimpulan. Luaran penelitian ini adalah (1) publikasi ilmiah dalam jurnal ber-ISSN bahkan jika memungkinkan publikasi ilmiah dalam jurnal nasional terakreditasi. (2) menyosialisasikan hasil penelitian kepada Pemerintah Daerah terkait di Kabupaten Buru dan aparatur Desa di Desa Wasbakat tentang pernikahan sasi ditinjau dari hukum adat.

Kata kunci: Implementasi; nilai; hukum adat; pernikahan sasi; wasbakat

\section{Pendahuluan}

Indonesia sebagai negara yang multikultural dan beragam baik bahasa, adat-istiadat, ras, suku, dan agama merupakan perekat kebangsaan nasional yang dapat menciptakan kerukunan umat beragama dengan tetap menjunjug tinggi norma-norma sosial yang berlaku. Prinsip nilai sosial yang terkandung dalam kehidupan suatu masyarakat hendaklah dijadikan parameter atau ukuran dalam membangun komunikasi yang sistemik yang dapat menghilangkan sikap desintegrasi bangsa secara fundamental.

Sehubungan dengan itu, sosio-kultural masyarakat yang terkandung di dalamnya berupa nilai kebersamaan, kekeluargaan, partisipatif, gotong-royong, bahu-membahu dalam melakukan kebaikan merupakan nilai-nilai sosial yang tumbuh dan berkembang dalam kehidupan masyarakat secara umum. Secara spesifik nilai tersebut juga dilakukan dalam kegiatan pernikahan sasi yang diadakan oleh masyarakat Desa Wasbakat Kecamatan Airbuaya Kabupaten Buru Provinsi Maluku.

Berdasarkan penelitian yang dilakuakn oleh (Judge \& Nurizka, 2008), Hukum adat sasi ini sangat efektif karena dengan adanya hukum adat sasi ini, maka masyarakat tidak berani untuk mengambil sumber daya alam sebelum waktu buka sasi. Ternyata dari kedua hukum ini yaitu hukum adat dan hukum positif mempunyai kedudukan yang saling terkait antara satu dengan yang lain.

Sasi merupakan salah satu bentuk adat istiadat yang mengandungtabu dimana terdapat sifat larangan dan kewajiban bagi masyarakat setempat. Sasi memang dianggap tradisional, bahkan di zaman modern seperti ini masyarakat setempat diMaluku sudah mulai mengabaikan tradisi dan adat istiadat yang mereka miliki (Zaen, 2011).

Tradisi pernikahan sasi yang dilakukan oleh komunitas tersebut pada prinsipnya memperkenalkan bahwa setiap masyarakat dalam kehidupannya terdapat nilai yang harus direkonstruksi dalam membangun jiwa sosial yang baik, sehingga dengan hal yang demikan diharapkan anggota masyarakat dapat mengetahui, memaknai, menghayati secara komprehensif hakikat nilai dalam hidup. Nilai merupakan sesuatu yang amat berharga dan dianggap penting oleh manusia, dengan nilai seseorang bisa membedakan antara yang hak 
dan yang batil, salah atau benar, tergantung sudut pandang seseorang dalam menginterprestasikan atau menafsirkan tentang konsep itu.

Beranjak dari pernyataan di atas, masyarakat Maluku pada umumnya dan masyarakat Desa Wasbakat Kecamatan Airbuaya pada khususnya, dalam melestarikan nilai-nilai sosial dalam pernikahan sasi sebagaimana yang diuraikan dalam pernyataan sebelumnya telah mengambarkan tentang hubungan solidaritas yang amat mengesankan dalam menjajaki pernikahan dimaksud. Nilai-nilai kebersamaan, kekeluargaan, musyawarah mufakat, gotong royong dan partisipatif selalu dijunjung tinggi oleh masyarakat setempat.

Proses pernikahan sasi yang dilakukan oleh sebagian masyarakat Maluku yang juga dilakukan oleh masyarakat Buru yang ada pada Desa Wasbakat kental dengan adat-istiadat termasuk adat dalam penyelenggaraan pernikahan. Dengan demikian, dipandang penting untuk menjelaskan apa sebenarnya definisi sasi yang sesungguhnya sehingga kita bisa menjelaskan secara detail mengenai dampak atau indikator pemberlakuan sasi dalam pernikahan yang diadakan oleh masyarakat Desa Wasbakat. Proses sasi adalah pihak lakilaki (ana mahana) yang berumur dewasa, telah sasi/ menandah perempuan (ana fina) yang sudah berumur dewasa, dengan berupa uang, sebanyak seratus ribu rupiah, dan sampai dengan yang tidak ditentukan nilainya, kepada pihak perempuan (ana fina) dan di situlah yang disebut dengan sasi/ditanda, maka seorang ana fina (perempuan) tidak bisa di jodohkan/diminang dengan laki-laki lain lagi, dan jika sudah disasi/ditanda, oleh kedua orang tua, lalu sewaktu-waktu dari pihak ana fina, terjadi penolakan atau tidak jadi kawin, maka pihak dari orang tua ana fina (perempuan) mengganti denda uang yang sebesar diberikan, dan ketika disasi ana fina (perempuan), ana mahana (laki-laki) juga ikut tinggal bersama di rumah perempuan, dan bahkan sampai tingkat berhubungan badan.

Pada umumnya, masyarakat Maluku hanya dikenal/diartikan dengan sasi sebagai tanda larangan, tetapi juga ada sasi di masyarakat Desa Wasbakat Kecamatan Airbuaya. Sasi sebagai tandah pengikat pada anak perempuan, dan sasi ini masih berlaku sampai sekarang di kalangan masyarakat adat Buru, yang berada di Desa Wasbakat Kecamatan Airbuaya, Kabupaten Buru.

Berdasarkan deskripsi di atas, penelitian ini bertujuan untuk mengkaji dan

menganalisis implementasi nilai-nilai perkawinan sasi menurut hukum adat di Desa Wasbakat, Kecamatan Airbuaya, Kabupaten Buru.

\section{Metode Penelitian}

Penelitian ini adalah penelitian hukum yuridis normatif, yaitu penelitian terhadap kaidah-kaidah hukum (peraturan perundang-undangan) yang relevan (Yusuf, 2015). Penelitian terhadap hukum positif ini dilakukan dengan cara mengevaluasi segi kesesuaian antara satu kaidah hukum dengan kaidah hukum yang lainnya, atau dengan asas-asas hukum yang diakui dalam praktek hukum yang ada.

Pendekatan masalah yang digunakan adalah: 
a. Pendekatan perundang-undangan (statute approach) yang adalah pendekatan dengan berdasarkan peraturan perundang-undangan yang berlaku khususnya mengatur tentang : Implementasi Nilai-Nilai Perkawinan Sasi Menurut Hukum Adat Di Desa Wasbakat Kecamatan Airbuaya Kabupaten Buru.

b. Pendekatan konseptual (conceptual approach), beranjak dari pandangan-pandangan dan doktrin-doktrin yang berkembang di dalam ilmu hukum peneliti akan menemukan ide-ide yang melahirkan pengertian-pengertian,konsep-konsep hukum,dan asas-asas hukum relevan dengan isu yang dihadapi. Pemaman akan pandangan-pandangan dan doktrin-doktrin.

\section{Hasil dan Pembahasaan}

\section{Perkawinan sasi}

Pada umumnya, masyarakat Maluku hanya dikenal/diartikan dengan sasi sebagai tanda larangan, tetapi juga ada sasi di masyarakat Desa Wasbakat Kecamatan Airbuaya. Sasi sebagai tandah pengikat pada anak perempuan, dan sasi ini masih berlaku sampai sekarang di kalangan masyarakat adat Buru, yang berada di Desa WasbakatKecamatan Airbuaya, Kabupaten Buru.

Saat ini, sasi memang lebih cenderung bersifat hukum bukan tradisi. Sasi digunakan sebagai cara mengambil kebijakan dalam pengambilan hasil laut dan hasil pertanian. Namun secara umum, sasi berlaku di masyarakat Maluku sebagai bentuk etika tradisional. Sasi tidak berhubungan dengan ritus kelahiran, perkawinan, kematian, dan pewarisan, melainkan lebih cenderung bersifat tabu dan kewajiban setiap individu dan masyarakat dalam mengelola Sumber Daya Alam yang dimiliki. Seperti yang kita tahu, bahwa taboo atau tabu berfungsi untuk menjaga kestabilan hidup masyarakat. Tabu seringkali dikaitkan dengan sesuatu yang terlarang, karena akan mengakibatkan dampak buruk bagi orang yang melanggar tabu. Seperti yang didefinisikan oleh Sigmund Freud tentang tabu, yaitu: "Suatu perilaku terlarang di mana terdapat kecenderungan kuat yang terdapat di dalam alam bawah sadar".

Tabu memang dianggap erat kaitannya dengan hal-hal kotor dan keramat, sehingga tidak boleh dilanggar. Karena jika melanggar tabu, akan mengalami hal buruk yang menimpa seseorang.

Lokollo menjelaskan bahwa terdapat enam tujuan falsafah yang mempengaruhi pelaksanaan adat sasi, yakni sebagai berikut :

a. Memberikan petunjuk umum tentang perilaku manusia, untuk memberikan batasan tentang hak-hak masyarakat

b. Menyatakan hak-hak wanita, untuk memberikan definisi status wanita dan pengaruh mereka dalam masyarakat

c. Mencegah kriminalitas, untuk mengurangi tindakan kejatahan seperti mencuri 
d. Mendistribusikan Sumber Daya Alam yang mereka miliki secara merata untuk menghindari konflik dalam pendistribusian sumber daya alam, yakni antara masyarakat dari desa atau kecamatan yang berbeda

e. Menentukan cara pengelolaan Sumber Daya Alam yang di laut dan di darat guna meningkatkan kesejahteraan masyarakat

f. Untuk penghijauan.

Sehubungan dengan itu, pengajuan sasi bisa diberlakukan dalam pernikahan jika ada hukum atau aturan yang dibangun dalam kesepakatan yang diambil secara bersama-sama. Maka kedudukan sasi tersebut dianggap penting dan berlaku dalam pernikahan yang diadakan oleh masyarakat dimaksud. Desa Wasbakat merupakan salah satu daerah yang masih menggunakan tradisi sasi yang dibangun dalam pernikahan.

Jika pihak laki-laki telah melakukan peminangan atau menghitbah pihak perempuan yang ingin dinikahi secara sah, menurut aturan undang-undang, maka dalam proses peminangan tersebut telah didudukan mengenai aspek yang ingin dicapai secara bersama termasuk mengenai dampak dari pertunangan tersebut.

Persetujuan antara para kedua belah pihak yang sudah berusia dewasa dan berakhir ketika perkawinan pada usia dewasa. Di Desa Wasbakat, jika salah satu pihak telah melalaikan kesepakatan yang telah dibangun dalam proses sasi yang diadakan, maka disitulah sanksi pernikahan diterapkan, apakah pihak ana mahana (laki-laki), atau pihak ana fina (perempuan), yang bersalah maka proses ganti rugi di berlakukan.Jika kedua belah pihak tidak memutuskan pertunangan yang telah dibangun berdasarkan kesepakatan maka sanksi tidak diberlakukan dalam pernikahan tersebut.

\section{Perkawinan dalam Persefektif Undang-Undang Nomor 1 Tahun 1974}

Pengertian nikah menurut undang-undang perkawinan, pencatatannya dapat dilakukan dikantor sipil, sedangkan pelaksanaan nikah dilakukan menurut aturan agama yang dianut. Apabila tidak dilakukan menurut agama yang dianutnya, maka perkawinan dianggap tidak sah menurut undang-undang perkawinan (Prodjohamidjojo, 2015)

Menurut pasal 2 undang-undang Nomor 1 tahun 1974 (BIP, 2017). Dari adanya pernikahan yang dibentuk, peran kontribusi suami dan istri sangatlah dominan dalam membentuk ikatan keluarga yang kuat dengan pondasi nilai-nilai kebaikan yang bermuarah pada ketaatan kepada Allah SWT, tuhan yang Maha Esa. Untuk mewujudkan ikatan pernikahan yang baik dan benar sesuai dengan ketentuan hukum yang berlaku, fungsi dasarnya adalah menghindari diri dari pertikaian dan perpecahan. Kedua belah pihak (suami/istri) bekerjasama dalam membangun rumah tangga atau keluarga tersebut (Lakburlawal, 2014). Hal semacam itu, sangatlah berdampak terhadap hak dan kewajiban masing-masing (Zulfiani, 2017). Hukum Islam menggambarkan sifat yang luhur bagi ikatan yang dijalin oleh dua orang berbeda jenis, yakni ikatan perkawinan. Ikatan perkawinan dalam hukum islam dinamakan dengan miitsyaaqanqholiidhon, yaitu suatu ikatan janji yang kokoh. Oleh karenanya, suatu 
ikatan perkawinan tidak begitu saja dapat terjadi tampa melalui beberapa ketentuan (Tutik, 2017).

\section{Perkawinan Menurut Hukum Adat}

Perkawinan Menurut Hukum Adat adalah salah satu peristiwa yang sangat penting dalam kehidupan masyarakat adat, sebab perkawinan bukan hanya menyangkut kedua mempelai, tetapi juga orang tua kedua belah pihak, saudara-saudaranya, bahkan keluarga mereka masing-masing. Dalam hukum adat perkawinan itu bukan hanya merupakan peristiwa penting bagi mereka yang masih hidup saja. Sistem perkawinan menurut hukum adat sebagai berikut; 1. Dalam hukum adat dikenal ada tiga sistem perkawinan yaitu: Sistem Endogami: yaitu seorang hanya dibenarkan mengadakan perkawinan dengan seseorang dalam suku sendiri. Sistem perkawinan ini sudah jarang terjadi. 2. Sistem Eksogami: yaitu perkawinan dengan seseorang yang berlainan suku atau suku yang lain. 3. Sistem Eleutherogami: yaitu sistem ini tidak mengenal larangan-larangan atau keharusankeharusan (Erwinsyahbana, 2012). Laranganlarangan dalam sistem ini adalah yang bertalian dengan ikatan kekeluargaan, yaitu: Nasab (sama dengan turunan yang dekat) seperti kawin dengan ibu, nenek, anak kandung, cucu, saudara kandung, saudara bapak atau ibu. Musyahara (sama dengan periparan), yaitu kawin dengan ibu tiri, menantu, mertua, anak tiri.

\section{Implementasi}

Implementasi dalam Kamus Besar Bahasa Indonesia diartikan sebagai pelaksanaan atau penerapan. Implementasi adalah suatu tindakan atau pelaksanaan dari sebuah rencana yang sudah disusun secara matang dan terperinci. Implementasi biasanya dilakukan setelah perencanaan sudah dianggap fix. Secara sederhana implementasi bisa diartikan pelaksanaan atau penerapan. Majone dan Wildavsky mengemukakan bahwa implementasi adalah perluasan aktivitas yang saling menyesuaikan.

Abdul Wahab Solichin mengemukakan bahwa implementasi adalah pelaksana keputusan kebijakan dasar, biasanya dalam bentuk Undang-Undang. Namun, dapat pula berbentuk perintah-perintah atau keputusan eksekutif yang penting atau badan peradilan lainnya, keputusan tersebut mengidentifikasikan masalah yang ingin diatasi, menyebutkan secara tegas tujuan atau sasaran yang ingin dicapai dengan berbagai cara untuk menstruktur atau mengatur proses implementasinya (Wahab, 2012).

Penelitian ini berpijak pada kajian hukum ada tkarena mengkaji implementasi nilai-nilai perkawinan sasi menurut hukum adat di Desa Wasbakat Kecamatan Airbuaya Kabupaten Buru. Berdasarkan rumusan masalah yang mengacu pada perkawinan sasi menurut hukum adat di Desa Wasbakat Kecamatan Airbuaya Kabupaten Buru maka skema penelitian ini akan mengidentifikasi dan menganalisis implementasi nilai-nilai perkawinan sasi menurut hukum adat di desa Wasbakat Kecamatan Airbuaya Kabupaten Buru. Sehingga, Out put dari penelitian ini adalah 
menemukan wujud implementasi nilai-nilai perkawinan sasi menurut hukum adat di desa Wasbakat Kecamatan Airbuaya Kabupaten Buru.

Untuk lebih jelasnya alur dan sistematika penelitian ini akan tergambarkan pada bagan kerangka pikir berikut.

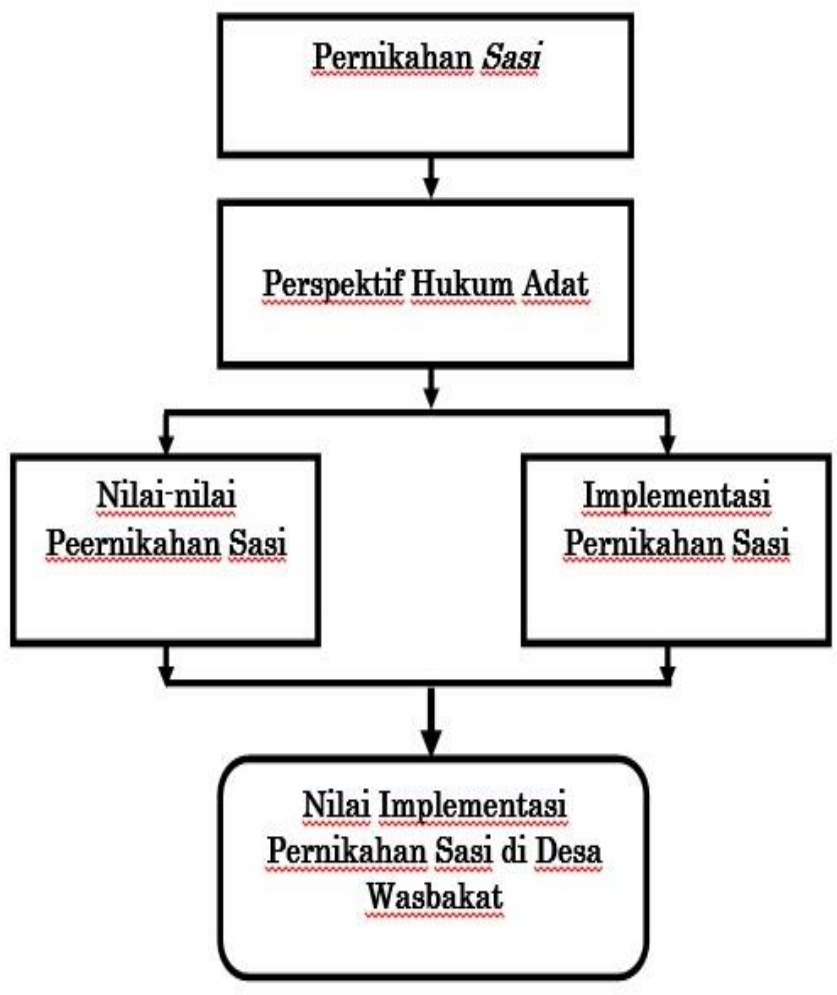

\section{Gambar 1 alur dan sistematika penelitian}

Penelitian terhadap hukum positif ini dilakukan dengan cara mengevaluasi segi kesesuaian antara satu kaidah hukum dengan kaidah hukum yang lainnya, atau dengan asas-asas hukum yang diakui dalam praktek hukum yang ada (Bagir, 2015). Pendekatan masalah yang digunakan adalah:

a. Pendekatan perundang-undangan (statute approach) adalah pendekatan dengan berdasarkan peraturan perundang-undangan yang berlaku khususnya mengatur tentang: Implementasi Nilai-Nilai Perkawinan Sasi Menurut Hukum Adat di Desa Wasbakat Kecamatan Airbuaya Kabupaten Buru.

b. Pendekatan konseptual (conceptual approach), beranjak dari pandangan-pandangan dan doktrin-doktrin yang berkembang di dalam ilmu hukum peneliti akan menemukan ide-ide yang melahirkan pengertian-pengertian, konsep-konsep hukum, dan asas-asas hukum relevan dengan isu yang dihadapi. Pemahaman akan pandangan-pandangan dan doktrin-doktrin tersebut merupakan sandaran bagi peneiti dalam membangun suatu argumentasi hukum dalam memecahkan isu yang dihadapi, yakni impelementasi nilai-nilai perkawinan sasi munurut hukum adat di Desa Wasbakat. 


\section{Kesimpulan}

Perkawinan sasi berlaku pada masyarakat adat buru yang berada di desa wasbakat kecamatan airbuaya, sebelum berlaku undang-undang perkawinan sasi masyarakat adat memberlakukan sasi yang terjadi di saat dalam kandungan ibu, tetapi dengan adanya hukum pemerintah, dan masyarakat mengikuti perkembangan informasih yang semakin pesat, lewat media masa, lewat pendidikan anak-anak yang berada di bangku perguruan tinggi, maka sasi tidak di berlakukan lagi dari sejak dalam kandungan, tetapi di berlakukan sejak ia lahir maupun ia besar, dan masyarakat adat masih menjalangkan nilai-nilai perkawinan sasi sampai sekarang berupa, sanksi-sanksi adat, yang di yang masih di berlakukan berupa sanksi adat atu nilai adat yaitu, humas lau, kalelei, honowain.

Sistem sasi yang di lakukan oleh masyarakat adat buru terkhususnya di desa wasbakat yang berada di kecamatan airbuaya sangat bertentangan, dan sasi pada dasarnya masyarakat adat yang beragama islam tidak menjalangkan sasi itu karna bertentangan dengan hukum islam maupun positif undang-undang perkawinan no 1 tahun 1974 yang suda di uba dengan undang-undang no 16 tahun 2019 (RI, 2019). Dan masyarakat adat buru yang beragama hindu dan kristen suda tidak menjalangkan sasi lagi tapi mereka suda menjalangkan sasi di sejak ia lahir dan berusia 10-15 tahun keatas, tetapi sanksi dari perkawinan adat dan nilainilai masih di jalangkan oleh masyarakat adat buru agar tidak hilang nilai adat yang dijalangkan oleh masyarakat setempat. 


\section{BIBLIGRAFI}

Bagir, M. (2015). Penelitian di Bidang Hukum, dalam jurnal Hukum Puslitbangkum Nomor 1-1999, Lembaga Penelitian Univ. Padjadjaran, Bandung.

BIP, Tim Redaksi. (2017). Tujuan dikeluarkannya Undang-undang Nomor 1 tahun 1974. Buana Ilmu Populer.

Erwinsyahbana, Tengku. (2012). Sistem hukum perkawinan pada Negara hukum berdasarkan pancasila. Jurnal Ilmu Hukum, 3(1).

Judge, Zulfikar, \& Nurizka, Marissa. (2008). Peranan Hukum Adat Sasi Laut dalam Melindungi Kelestarian Lingkungan di Desa Eti Kecamatan Seram Barat Kabupaten Seram Bagian Barat. Lex Jurnalica, 6(1), 18037.

Lakburlawal, Mahrita A. (2014). Kedudukan Suami Dalam Sistem Kekerabatan Masyarakat Adat Ditinjau Dari Perspektif Hak Asasi Manusia (Studi Pada Desa Letwurung Kecamatan Babar Timur Kabupaten Maluku Barat Daya). Sasi, 20(2), 3646.

Prodjohamidjojo, Martiman. (2015). Hukum Perkawinan Indonesia. Jakarta: CV. Karya Gemilang.

RI, UU. (2019). Undang-Undang Nomor 16 Tahun 2019 Tentang Perkawinan. Jakarta: Pustaka Yayasan Peduli Anak Negeri (YPAN).

Tutik, Titik Triwulan. (2017). Pengantar Hukum Perdata di Indonesia. Jakarta: Prestasi Pustaka.

Wahab, Solichin Abdul. (2012). Analisis kebijakan: dari formulasi ke penyusunan modelmodel implementasi kebijakan publik. Jakarta: Bumi Aksara, 77.

Yusuf, Muri. (2015). Metode Penelitian Kuantitatif, Kualitatif \& Penelitian Gabungan. Jakarta: Prenadamedia Group.

Zaen, Izza Laelatul Izzah. (2011). Kajian Literatur Maluku Menjaga Alam Seribu Pulau Dilema Sistem Adat Sasi dan Kuasa Pemerintah Menjaga Sumber Daya Alam Pulau Maluku.

Zulfiani, Zulfiani. (2017). Kajian Hukum terhadap Perkawinan Anak di Bawah Umur Menurut Undang-undang Nomor 1 Tahun 1974. Jurnal Hukum Samudra Keadilan, 12(2), 211-222. 